\title{
Effects of fine aggregate abrasion resistance and its fineness module on wear resistance of Portland cement concrete pavements
}

\author{
Efecto de la resistencia al desgaste del agregado delgado y la resistencia al desgaste en las mezclas \\ de concreto de cemento Portland de módulo
}

\author{
Orhan Karpuz (Main author) \\ Gümüşhane University, Faculty of Engineering and Natural Sciences, Civil Engineering Department \\ orhankarpuz@hotmail.com
}

\section{Muhammet Vefa Akpinar}

Karadeniz Technical University, Engineering Faculty, Civil Engineering Department

mvakpinar@ktu.edu.tr

\section{Metin Mutlu Aydin (Corresponding Author)}

Akdeniz University, Engineering Faculty Civil Engineering Department.

07158, Antalya, Turkey, Tel: 905062699149

metinmutluaydin@akdeniz.edu.tr

Manuscript Code: 723

Date of Acceptance/Reception: 23.03.2017/05.01.2016

DOI: 10.7764/RDLC.16.1.126

\begin{abstract}
In this research, effects of fine aggregate abrasion resistance and its fineness module on wear resistance of Portland cement concrete pavements studied. Concrete samples included fine crushed limestone aggregate, fine crushed limestone-basalt mixture, and fine crushed basalt aggregate. The study results showed that LA abrasion rate of $30 \%$ or less of fine aggregates would be necessary for long lasting concrete roads. Furthermore, it was found that fine aggregate's fineness module of 3.15 will significantly increase concrete road surface's wear resistance. As the fine aggregate's fineness module value increased from 2.2 to 3.15 , the concrete's wear amount decreased to $15.5 \%$. Study findings also showed that using basalt aggregates instead of widely used limestone aggregates, will significantly increase pavement concrete wear resistance.
\end{abstract}

Key words: Abrasion resistance; concrete pavement; fine aggregate; fineness modüle; Portland cement.

\section{Resumen}

En este estudio se han investigado los efectos de la resistencia al desgaste del agregado delgado y la resistencia al desgaste en los bloques de concreto de cemento portland de monitoreo de módulo. Las muestras de concreto consisten en piedra caliza molida, mezcla finamente molida de piedra calizabasalto y agregados de basalto finamente molido. Los resultados obtenidos de los análisis realizados muestran que en los caminos de concreto duraderos los agregados finos deben tener un índice de pérdida de 30\% o menos en Los Ángeles (LA). Además, los resultados muestran que la delgadez del módulo de módulo de elasticidad de 3,15 ha aumentado significativamente el exceso de resistencia de los caminos de concreto. Se ha determinado que el aumento del valor de módulo fino del módulo de 2,2 a 3,15 reduce la cantidad de desgaste del concreto en un 15,5\%. Además, a partir de los resultados del estudio, se ha encontrado que el uso de agregados de basalto en lugar de agregados de piedra caliza comúnmente usados ha aumentado significativamente la resistencia al desgaste de los revestimientos de concreto.

Palabras clave: resistencia al desgaste, recubrimiento de concreto, agregado fino, módulo de finura, cemento Portland.

\section{Introduction}

Material loss as a consequence of friction on concrete road surfaces is usually caused by snow plow blades, studded and chain motor wheels. Although this is a slow physical and mechanical event, as its durability in the time carries this event to a great dimension, it is extremely important. Many researchers surveying on wear resistance of concrete claim that wear resistance of concrete mainly depends on characteristics of concrete's compressive strength, microstructure of the surface which is exposed to abrasive strength, surface finishing features and testing methods (Atiş, 2002; Cabrera, 1985; Gjørv, Baerland \& Ronning, 1990; Sadegzadeh, Page \& Kettle, 1987; Vorvolakos, 1983). Concrete being a composite material is composed of two main phases such as coarse aggregate and mortar phases. Wear resistance of the concrete depends on the one that is more resistant (Ozturan, 1984). Aggregate is the main bearing component of the concrete (Gutiérrez Moreno, Mungaray Moctezuma \& Hallack Alegría, 2015; Karpuz, 2008; Malheiro, Meira \& Lima, 2016; Uygunoglu, 2016). The wear resistance of high strength concretes which are mixed with strong aggregates are also high (Laplante, Aitcin \& Vézina, 1991; Liu, 1981; Smith, 1958). Although the wear resistance of artificial hard aggregates such as blast furnace slag and natural aggregates like basalt and granite are higher, they increase the operating cost since they cause more abrasion and corrosion in their mechanic portions of their rock crusher settings. 
However, it is necessary to benefit from this property of hard aggregates in concrete roads. Concrete resistance's being inadequate against to abrasive strengths will cause a decrease of concrete slab thickness and as a result, the event called 'dusting' will occur on the concrete surface. When the thickness decrease, tensile stress will increase and thus tension cracks will become widespread and as a result, the road's service life will be shortened

(Gjørv et al., 1990; Hosking, 1992).

\section{Description of the problem}

Mortar phase that is under contact with tire is composed of fine aggregate and cement paste. These fine aggregates have a direct effect on the friction of concrete roads surfaces (Hall, 2003; Henry, 2000). In this study, effects of fine aggregate abrasion resistance and its fineness module on wear resistance of Portland cement concrete pavements were studied. For this purpose limestone, basalt and fine aggregates of limestone and basalt equal mixtures were used in gradations having three different fineness moduli.

\section{Experimental study}

\section{Materials}

Coarse mineral aggregate and some fine mineral aggregate that is used in this study are chosen from limestone origin aggregate widely used in the construction sector as main pavement construction material. Fine Limestone origin aggregate that has high wear resistance used was provided from Basalt quarry of Yomra town of Trabzon province from Güsey concrete power plant. In concrete mixtures, Portland Cement 42.5 produced by Aşkale Trabzon Cement Factory was used. The physical and chemical properties of the cement were shown in Table 1.

Table 1. Properties of cement.Source: self-elaboration.

\begin{tabular}{lrlc}
\multicolumn{3}{c}{ Table 1. Properties of cement.Source: self-elaboration. } \\
\hline Physical and mechanical properties & \multicolumn{2}{c}{ Chemical analysis (\%) } \\
\hline Unit mass & 3.15 & $\mathrm{SiO}_{2}$ & 20.06 \\
Specivic surface $\left(\mathrm{cm}^{2} / \mathrm{g}\right)$ & 3410.00 & $\mathrm{Al}_{2} \mathrm{O}_{3}$ & 5.16 \\
Retained by 200 mikron sieve (\%) & 0.10 & $\mathrm{Fe}_{2} \mathrm{O}_{3}$ & 3.16 \\
Retained by 90-micron sieve (\%) & 3.10 & $\mathrm{CaO}$ & 62.43 \\
Compressive strength (MPa), 2 days & 24.50 & $\mathrm{MgO}$ & 2.82 \\
7 days & 42.00 & $\mathrm{SO}_{3}$ & 2.32 \\
28 days & 44.40 & $\mathrm{~K}_{2} \mathrm{O}$ & 0.60 \\
& & $\mathrm{TiO}_{2}$ & 0.20 \\
& & $\mathrm{Na}_{2} \mathrm{O}$ & 0.36 \\
& & $\mathrm{Sulph}$ & 0.17 \\
& & Chlorine & 0.04 \\
& & Ignition loss & 1.55 \\
& & Insoluble residue & 1.05 \\
\hline
\end{tabular}

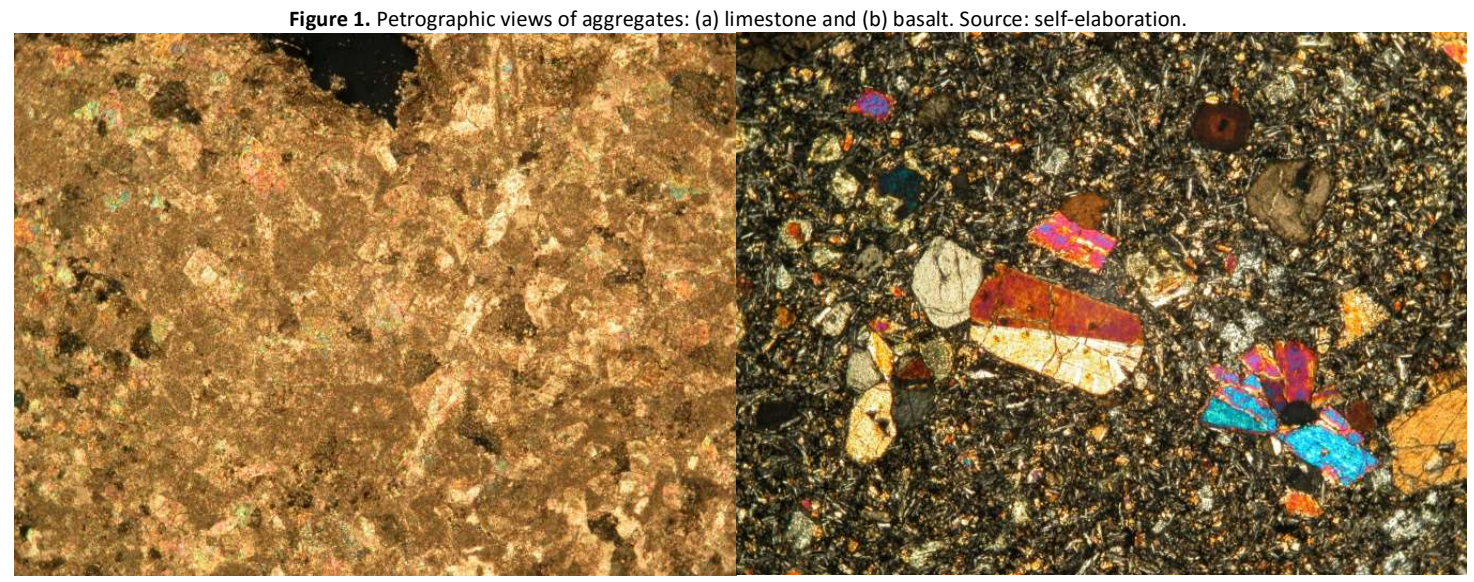

(a)

(b) 
Figure 1 shows that limestone can be classified as biosparit type and has sparit cement, fossil parts and calcite droplets. Basalt, on the other hand, was composed of plagioclase (An 50-68), pyroxene, olivine materials and was microlith, porphyritic and glomeraphiric textured. It was seen that chloritization and silification existed. Unit mass, water absorption (24 hours), natural water ratio and Los Angeles (LA) abrasion tests are conducted on coarse and fine aggregates and the results are shown in Table 2.

\begin{tabular}{lccccc}
\multicolumn{4}{c}{ Table 2. Characteristics of coarse and fine aggregate. Source: self-elaboration. } \\
\cline { 2 - 3 } Characteristics & \multicolumn{2}{c}{ Limestone } & & Limestone + Basalt & Basalt \\
\cline { 2 - 3 } & Coarse & Fine & & Fine & Fine \\
\hline Dry Unit Mass $\left(\mathrm{gr} / \mathrm{cm}^{3}\right)$ & 2.70 & 2.57 & 2.69 & 2.98 \\
Saturated Unit Mass $\left(\mathrm{gr} / \mathrm{cm}^{3}\right)$ & 2.72 & 2.63 & 2.75 & 3.02 \\
Natural Unit Mass $\left(\mathrm{gr} / \mathrm{cm}^{3}\right)$ & 2.70 & 2.58 & 2.72 & 3.01 \\
Water Absorption, (\%) & 0.74 & 2.33 & 2.06 & 1.45 \\
Water Content, (\%) & 0.10 & 0.40 & 1.20 & 1.03 \\
Abrasion Ratio, (\%) (Los Angeles) & 28.5 & 33.1 & 27.8 & 21.3 \\
\hline
\end{tabular}

General directorate of highways' technical specifications (Turkey General Directorate of Highways, 2006) for road wearing surface coats LA value to be no more than $30 \%$. Therefore, aggregates used in the study are appropriate for the concrete road surface. $\mathrm{P}(\%)$ passing values of sieved aggregate used were shown in Table 3.

\begin{tabular}{lccc}
\multicolumn{4}{c}{ Table 3. Gradations of aggregate mixes. Source: self-elaboration. } \\
\cline { 2 - 4 } \multicolumn{2}{c}{ Sieve Size/No } & \multicolumn{3}{c}{ Passing (\%) } \\
\hline 5/8" & (Aggregate A) & (Aggregate B) & (Aggregate C) \\
$5 / 16^{\prime \prime}$ & 100 & 100 & 100 \\
No.5 & 73 & 73 & 73 \\
No.10 & 41.70 & 41.70 & 41.70 \\
No.18 & 31.27 & 27.10 & 20.85 \\
No.35 & 22.93 & 16.68 & 8.34 \\
No.60 & 14.60 & 8.34 & 4.17 \\
Pan & 6.25 & 2.09 & 2.09 \\
\hline
\end{tabular}

The aggregate consists of $57 \%$ coarse and $43 \%$ fine aggregate. The amount of the material in the fresh concrete was computed based on fixed amount of water/cement ratio, cement content, fine aggregate and $2 \%$ air. Table 4 shows that the material amounts used in $1 \mathrm{~m} 3$ concrete mixtures. In the mixtures, drinkable water and Sikament R4 superplasticizer concrete admixture ( $1 \%$ of cement mass) were used. The concrete mixtures that have limestone fine aggregate were enumerated as $L$, basalt was shown with $B$, the mixture has $50 \%$ limestone and $50 \%$ basalt were shown with LB. Fine aggregate fineness module of 2.2, 2.7 and 3.15 are shown $a, b$ and c, respectively.

Table 4. The material amounts used in $1 \mathrm{~m} 3$ concrete mixtures. Source: self-elaboration.

\begin{tabular}{lcccccccc}
\hline $\begin{array}{l}\text { Fine } \\
\text { aggregate }\end{array}$ & $\begin{array}{c}\text { Concrete } \\
\text { No }\end{array}$ & $\begin{array}{c}\text { Cement } \\
(\mathrm{kg})\end{array}$ & $\mathrm{w} / \mathrm{c}$ & $\begin{array}{c}\text { Water } \\
(\mathrm{kg})\end{array}$ & $\begin{array}{c}\text { Super } \\
\text { Plasticizer } \\
(\mathrm{kg})\end{array}$ & $\begin{array}{c}\text { Coarse } \\
\text { Aggregate } \\
(\mathrm{kg})\end{array}$ & $\begin{array}{c}\text { Fine } \\
\text { Aggregate } \\
(\mathrm{kg})\end{array}$ & $\begin{array}{c}\text { Slump } \\
(\mathrm{cm})\end{array}$ \\
\hline Limestone & $\mathrm{La}$ & 400 & 0.40 & 183 & 4 & 1064.48 & 765.21 & 2.5 \\
& $\mathrm{Lb}$ & 400 & 0.40 & 183 & 4 & 1064.48 & 765.21 & 3.0 \\
& $\mathrm{LC}$ & 400 & 0.40 & 183 & 4 & 1064.48 & 765.21 & 5.0 \\
Limestone + & $\mathrm{LBa}$ & 400 & 0.40 & 174 & 4 & 1064.48 & 810.19 & 2.5 \\
Basalt & $\mathrm{LBb}$ & 400 & 0.40 & 174 & 4 & 1064.48 & 810.19 & 3.0 \\
& $\mathrm{LBC}$ & 400 & 0.40 & 174 & 4 & 1064.48 & 810.19 & 5.0 \\
Basalt & $\mathrm{Ba}$ & 400 & 0.40 & 171 & 4 & 1064.48 & 893.58 & 2.5 \\
& $\mathrm{Bb}$ & 400 & 0.40 & 171 & 4 & 1064.48 & 893.58 & 3.0 \\
\hline
\end{tabular}


$\mathrm{Bc}$

400

$0.40 \quad 171$

1064.48

893.58

4.0

Although fixed water/cement (w/c) ratios were used, the water amounts differed from each other (Table 4). Because humidity of the aggregate are different and they were taken as saturated surface dry. The total water amount was maintained the same in all mixtures. Fresh concrete samples whose mixtures were prepared in accordance with the information above (Table 4) were put into 150x150x150 mm cubic molds for compressive strength test and into 100x100x400 mm beam molds for Bohme abrasion resistance test. Their surfaces were covered with wet rags, then after 24 hours later they were taken from molds and put into water of $20^{\circ} \mathrm{C}$ and left in this water for 28 days. Concrete samples to be used in LA abrasion experiment were prepared by cutting from beam samples.

\section{Tests}

Compressive Strength Test. According to the objective of the study, $150 \mathrm{~mm}$ cubic samples taken from concrete mixtures were subjected to 28 days cure in accordance with TS EN 12390-3 (2010) standards. After being taken from cure pool they were left for one day in normal room conditions and later they were broken under uniaxial compression in the speed of $1 \mathrm{MPa} / \mathrm{s}$.

Wear Resistance Test. Bohme wear resistance test was used in determining concrete's wear resistance according to TS 2824 EN 1338 (2009) standards. In this test set up, there is an abrasive rotating steel disc of 750 mm diameter which has the circulation of $30 \pm 1$ per minute placed horizontally. $294 \pm 3 \mathrm{~N}$ vertical force is used on the concrete sample which is put on its place on rotating disc and fixed. On the setup, there is an automatic stopping system after 22 rotations. 3 same samples of each concrete mixture were prepared according to the standard. Corundum (Al2O3) powder was spread on the trace of friction. After 22 rotations the concrete sample is rotated around its vertical axis in clockwise rotation of 900 . By the help of a suitable brush, the particles and sample remaining were cleaned and new powder was spread. Each sample in the content of the study is subjected to 440 rotations in total that is 20 times 22 rotations. In order to determine the abrasion amount of the samples after the test which were cut according to the indicated measures of the produced concrete's thickness measurements were made before and after the test. Measurements of caliber gage of 0.01 accuracy and height were taken on three points of the each side of the samples and one point in the middle, totally on nine points.

\section{Results and discussion}

The compressive strength of the prepared concretes and Bohme wear resistance test result values were shown in Table 5 .

\begin{tabular}{lcccc}
\multicolumn{5}{c}{ Table 5. Results of compressive strength and Bohme wear resistance tests. Source: self-elaboration. } \\
\hline $\begin{array}{cccc}\text { Concrete } \\
\text { No }\end{array}$ & $\begin{array}{c}\text { Fine Agg. } \\
\text { LA Abrasion } \\
(\%)\end{array}$ & $\begin{array}{c}\text { Fine Agg. } \\
\text { Fineness } \\
\text { Module }\end{array}$ & $\begin{array}{c}\text { Mean } \\
\text { Compressive } \\
(\mathrm{MPa})\end{array}$ & $\begin{array}{c}\text { Mean } \\
\text { Böhme Wear } \\
\left(\mathrm{mm} / 50 \mathrm{~cm}^{2}\right)\end{array}$ \\
\hline $\mathrm{La}$ & 33.1 & 2.2 & 62 & 5.19 \\
$\mathrm{Lb}$ & & 2.7 & 64.6 & 4.67 \\
$\mathrm{LC}$ & & 3.15 & 65.7 & 3.76 \\
$\mathrm{LBa}$ & 27.8 & 2.2 & 62.5 & 4.58 \\
$\mathrm{LBb}$ & & 2.7 & 64.2 & 3.80 \\
$\mathrm{LBC}$ & & 3.15 & 65.6 & 3.65 \\
$\mathrm{Ba}$ & 21.3 & 2.2 & 62.1 & 3.84 \\
$\mathrm{Bb}$ & & 2.7 & 63.6 & 3.49 \\
$\mathrm{BC}$ & & 3.15 & 66.0 & 3.25 \\
\hline
\end{tabular}

Most highway states specify in the USA as well as in Turkey, the percentage of wear of crushed stone or gravel not to exceed $55 \%$. For concrete with a 28 day design strength should be greater than $50 \mathrm{MPa}$, and the wear is not allowed to exceed 40\%. The American Concrete Institute (ACI) Committee 201 (2016) recommends that the compressive strength of concrete under abrasive forces should be over $30 \mathrm{MPa}$.

The experimental study results agreed with the findings of Siddique (2003), Siddique, Kapoor, Kadri \& Bennacer (2012) and Adewuyi, Sulaiman \& Akinyele (2017) that abrasion resistance of concrete increased with compressive strength for all mix proportions. Similar trends were observed on graphs by Singh \& Siddique (2012). The decrease in concrete wear 
loss can be attributed to the fines improved strength of the concrete, as abrasion resistance increased with increasing compressive strength as would normally be expected.

Compressive strength test results differed very little according to fine aggregate's rock type. The lowest values of compressive strength were 62-62.5 MPa in concretes having fine aggregates with 2.2 fineness module. Maximum values of compressive strength were 65.6-66.0 MPa in concretes having fine aggregates with 3.15 fineness module. If the fine aggregate's fineness module value increases, the compressive strength of concrete also increases to some extent (5$6.3 \%)$ in all fine aggregate types. However, this increase is very small.

In the Bohme wear test results, the most wear was seen in limestone origin concrete in which fine aggregate having 2.2 fineness module was used, with the value of $5.19 \mathrm{~mm}$. The least wear was encountered in concrete mixed basalt origin fine aggregate having 3.15 fineness module, with the value of $3.25 \mathrm{~mm}$. Concrete's wear resistance is effected by fine aggregate's fineness module and especially LA wear resistance to a great extent.

When the fine aggregate's fineness module increases from 2.2 to 3.15 the decrease of wear value of concrete was seen to be $\mathbf{2 7 . 5 \%}$ in limestone fine aggregate, on the other hand, this decrease in the limestone-basalt fine aggregate mixture was seen to be $20.3 \%$ and $15.4 \%$ in basalt fine aggregate. There was $44 \%$ of the difference between wear values of limestone and basalt mixtures (Figure 2). It was understood that the effect of fine aggregate's fineness module on concrete's wear resistance is much higher in fine aggregate having low LA wear resistance. There is a high negative correlation $\left(R^{2}=1\right)$ between concrete wear and fineness modulus for varying $L A$ values. Equation and correlation coefficient are shown in each of the figures. A correlation coefficient value $\left(R^{2}=1\right)$ indicates that there is a strong relationship between concrete wear and Fineness modulus for varying LA values. An increase fineness modulus lead to an increase in wear resistance of concrete.

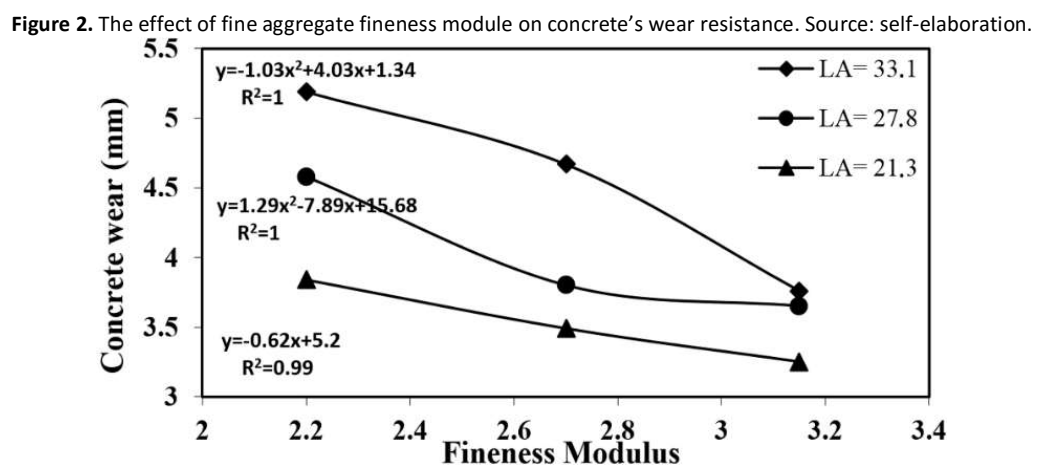

In passing from limestone to basalt, 35.6\% improvement of fine aggregate's abrasion resistance versus the increase of concrete's wear resistance become $26 \%$ in 2.2 fineness module, $25 \%$ in 2.7 fineness module and $13.6 \%$ in 3.15 fineness module. Fine aggregate's fineness module being more than 2.7 contributed a lot in terms of decreasing concrete's tendency towards wear (Figure 3). Equation and correlation coefficient are shown in each of the figures. A correlation coefficient value $\left(R^{2}=1\right)$ indicates that there is a strong relationship between concrete wear and LA abrasion ratio for varying finess modules. An increase LA abrasion ratio lead to an increase in wear resistance of concrete.

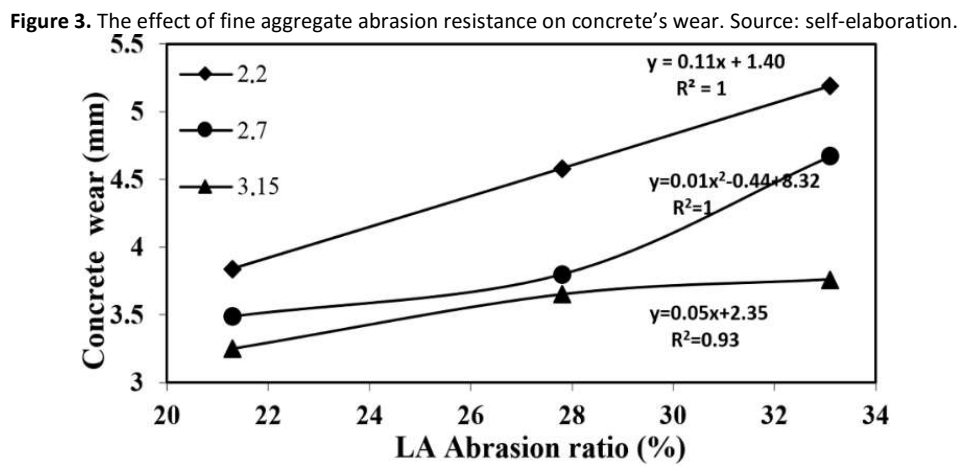


According to study results when fine aggregate's abrasion resistance increased concrete's wear decreased. The concretes which were produced with fine aggregate having little fineness module revealed itself more in this respect. As the abrasion resistance of fine aggregate decreased the impact of fineness module became apparent. When coarsegrained fine aggregate was used, concrete's wear resistance was affected less from fine aggregate's abrasion resistance. There was no remarkable increase in concrete's compressive strength with high abrasion resistance fine aggregates. It can be inferred that on the fracture behavior, gradation plays more active role than aggregate's origin despite the serious increase of concrete's wear resistance. It can be said that fine aggregate abrasion resistance is not dominated by cement-fine aggregate mortar with coarse aggregate.

LA abrasion loss, even if they are in the size of sand, has more effects on concrete wear resistance than compressive strength. Because of the fact that it increases costs due to its high erosive effect in stone chips plants, hard rocks are not preferred much. Using hard aggregate formed from competent rocks will contribute a lot concrete's wear resistance unless it causes a danger in terms of alkali-aggregate reaction.

Considering the fact that fine aggregate is in a considerable amount in near to the concrete road surface it can also be easily said that by improving concrete's wear resistance, the friction coefficient between the road surface and the tire will keep its competence longer. Road surface can be effected less during snow plowing operations, less wear-scouring will occur in tire-road contact track due to studded-chained tires and vehicles will run for longer time in safe.

Based on the findings of this study, for long lasting concrete roads with less mechanical wear, it can be advised that fine aggregate's fineness module value should be kept higher than 2.7. Similarly, using fine aggregate having high abrasion resistance as far as possible, especially whose LA abrasion test result are under $30 \%$ will be beneficial.

\section{Further Study}

The experimental study did not cover environmental effects such as low temperature and humidity which do have effects on the wear resistance. The accepted standard tests applied in this research study gives results only for the given temperatures and humidity limits specified by the standards. The extreme temperature and humidity limits may give different results. The current study is focused on applying the same concept on the accelerated pavement testing facility, APT, where actual single axle loads are applied over a very short period of time. The APT facilities have become more popular since they represent the field condition and loads better than the specified tests and small size samples.

The samples studied in this test program were cured for 28 days. However, in reality wear of concretes starts as soon as the pavement is open to traffic. Considering that concretes gains strength by time, more abrasion may occur during the first weeks on the concrete pavement surface. APT facilitiy testing or insute testing and observation would bemore realistic.

\section{Conclusions}

The following results were reached from the data gathered from this experimental study carried out in order to determine the effect of fine aggregate abrasion resistance and its fineness module on concrete's wear resistance:

- When the fine aggregate's fineness module value increased from 2.2 to 3.15, concrete's compressive strength results increased to $5-6.3 \%$, depending upon fine aggregate's abrasion resistance.

- As the fine aggregate's fineness module value increased from 2.2 to 3.15, the concrete's wear amount declined to $15.5-27.5 \%$, depending on the fine aggregate's abrasion resistance. As the fine aggregate's abrasion resistance increased, the effect of fine aggregate's fineness module on concrete's wear resistance declined.

- The minimum wear ratio (4.6\%) was realized in concrete samples of basalt fine aggregates having 3.15 fineness module.

- Instead of limestone origin aggregate which is widely used in concrete plants, using aggregates such as basalt that are more resistant to wear as fine aggregates will make a major contribution to increasing concrete road surface's wear resistance.

- For a long lasting concrete road, it can be advised to maintain the value of fine aggregate's LA abrasion rate $30 \%$ or less. Furthermore, it can be said that fine aggregate's fineness module being around 3.15 will do a great contribution to increase concrete road surface's wear resistance. 
ACI. (2016). 201.2R-16 Guide to Durable Concrete. Technical Documents.

Adewuyi, A. P., Sulaiman, I. A., \& Akinyele, J. O. (2017). Compressive Strength and Abrasion Resistance of Concretes under Varying Exposure Conditions. Open Journal of Civil Engineering, 7(1), 82-99. https://doi.org/10.4236/ojce.2017.71005

Atiş, C. D. (2002). High Volume Fly Ash Abrasion Resistant Concrete. Journal of Materials in Civil Engineering, 14(3), 274-277. https://doi.org/10.1061/(ASCE)0899-1561(2002)14:3(274)

Cabrera, J. G. (1985). The use of pulverized fuel ash to produce durable concrete. In Improvement of concrete durability (pp. 29-57). London, UK: Thomas Telford Limited. https://doi.org/10.1680/iocd.02456.0002

Gjørv, O. E., Baerland, T., \& Ronning, H. R. (1990). Abrasion resistance of high-strength concrete pavements. Concrete International, $12(1)$, 45-48.

Gutiérrez Moreno, J. M., Mungaray Moctezuma, A., \& Hallack Alegría, M. (2015). Reuse of Hydraulic Concrete Waste as a New Material in Construction Procedures: a Sustainable Alternative in Northwest Mexico. Revista de La Construcción, 14(2), 51-57. https://doi.org/10.4067/S0718 $915 \times 2015000200007$

Hall, J. W. (2003). Guide for pavement friction. NCHRP Project 1-43, Transportation sector of applied research associates. Washington D.C, USA.

Henry, J. J. (2000). Evaluation of pavement friction characteristics. NCHRP Synthesis 291, TRB. Washington D.C., USA: National Academy Press.

Hosking, R. (1992). Road aggregates and skidding. London, UK.

Karpuz, O. (2008). Investigation of concrete pavement fine aggregate effects on texture abrasion. Karadeniz Technical University, Trabzon, Turkey.

Laplante, P., Aitcin, P. -C., \& Vézina, D. (1991). Abrasion Resistance of Concrete. Journal of Materials in Civil Engineering, 3(1), 19-28. https://doi.org/10.1061/(ASCE)0899-1561(1991)3:1(19)

Liu, T. C. (1981). Abrasion resistance of concrete. In ACl Journal (Vol. 78, pp. 341-350).

Malheiro, R., Meira, G. R., \& Lima, M. (2016). Experimental stydy of chloride transport into double layered components with concrete and rendering mortar. Revista de La Construcción, 15(3), 119-132. https://doi.org/10.4067/S0718-915X2016000300012

Ozturan, T. (1984). Investigation abrasion resistance of concrete as a two-phase composite material, Phd Thesis. İstanbul Technical University, İstanbul Turkey.

Sadegzadeh, M., Page, C. L., \& Kettle, R. J. (1987). Surface microstructure and abrasion resistance of concrete. Cement and Concrete Research, 17(4), 581-590. https://doi.org/10.1016/0008-8846(87)90131-1

Siddique, R. (2003). Effect of fine aggregate replacement with Class F fly ash on the mechanical properties of concrete. Cement and Concrete Research, 33(4), 539-547. https://doi.org/10.1016/S0008-8846(02)01000-1

Siddique, R., Kapoor, K., Kadri, E.-H., \& Bennacer, R. (2012). Effect of polyester fibres on the compressive strength and abrasion resistance of HVFA concrete. Construction and Building Materials, 29, 270-278. https://doi.org/10.1016/j.conbuildmat.2011.09.011

Singh, G., \& Siddique, R. (2012). Abrasion resistance and strength properties of concrete containing waste foundry sand (WFS). Construction and Building Materials, 28(1), 421-426. https://doi.org/10.1016/j.conbuildmat.2011.08.087

Smith, F. (1958). Effect of Aggregate Quality on Resistance of Concrete to Abrasion. In Cement and Concrete (pp. 91-91-16). West Conshohocken, PA USA: ASTM International. https://doi.org/10.1520/STP39463S

TSE. (2009). TS 2824 EN 1338: Concrete paving blocks-Requirements and test methods.

TSE. (2010). TS EN 12390-3: Testing hardened concrete-Part 3-Compressive strength of test specimens.

Turkey General Directorate of Highways. (2006). Highways technical specification. Ankara, Turkey.

Uygunoglu, T. (2016). Comparison of properties of prefabricated interlocking pavement blocks cured at different conditions. Revista de La Construcción, 15(2), 125-134. https://doi.org/10.4067/S0718-915X2016000200013

Vorvolakos, T. N. (1983). Long term durability tests for high PFA content concrete. Unpublished. The University of Leeds, England. 